"TARGET2 imbalances: causes, assessments and consequences"

\begin{tabular}{|c|c|}
\hline AUTHORS & $\begin{array}{l}\text { Michael Menrad (D http://orcid.org/0000-0002-5493-3522 } \\
\mathbb{R} \text { http://www.researcherid.com/rid/U-6694-2017 }\end{array}$ \\
\hline ARTICLE INFO & $\begin{array}{l}\text { Michael Menrad (2020). TARGET2 imbalances: causes, assessments and } \\
\text { consequences. Banks and Bank Systems, 15(1), 107-117. } \\
\text { doi:10.21511/bbs.15(1).2020.11 }\end{array}$ \\
\hline DOI & http://dx.doi.org/10.21511/bbs.15(1).2020.11 \\
\hline RELEASED ON & Friday, 20 March 2020 \\
\hline RECEIVED ON & Saturday, 31 August 2019 \\
\hline ACCEPTED ON & Wednesday, 26 February 2020 \\
\hline LICENSE & $\begin{array}{l}(\mathrm{cc}) \mathrm{EY} \\
\text { This work is licensed under a Creative Commons Attribution } 4.0 \text { International } \\
\text { License }\end{array}$ \\
\hline JOURNAL & "Banks and Bank Systems" \\
\hline ISSN PRINT & $1816-7403$ \\
\hline ISSN ONLINE & $1991-7074$ \\
\hline PUBLISHER & LLC "Consulting Publishing Company "Business Perspectives" \\
\hline FOUNDER & LLC "Consulting Publishing Company "Business Perspectives" \\
\hline
\end{tabular}

NUMBER OF REFERENCES

48

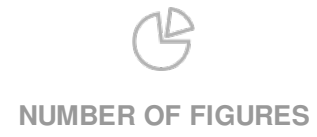

3
NUMBER OF TABLES

3

(C) The author(s) 2021. This publication is an open access article. 


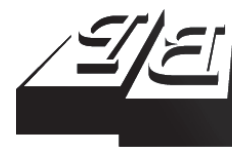

BUSINESS PERSPECTIVES

(O)

LLC "CPC "Business Perspectives" Hryhorii Skovoroda lane, 10, Sumy, 40022, Ukraine www.businessperspectives.org

Received on: $31^{\text {st }}$ of August, 2019 Accepted on: $26^{\text {th }}$ of February, 2020 Published on: $20^{\text {th }}$ of March, 2020

(C) Michael Menrad, 2020

Michael Menrad, Ph.D. Candidate, Doctoral School of Economic and Management Sciences, Doctor of Philosophy (Ph.D.) Program, Kaposvár University, Hungary.

\section{TARGET2 IMBALANCES: CAUSES, ASSESSMENTS AND CONSEQUENCES}

\begin{abstract}
This research aims to enrich the literature on the threatening topic of Target 2 imbalances in the euro area. Using a quantitative time series analysis, the paper examines and discusses the development of Target2 imbalances and the interrelationships of the European Central Bank (ECB) activities through market intervention using quantitative easing. This paper outlines the scope of central bank activities in different Eurozone countries and examines how individual debtor and creditor countries, as well as central banks, will continue to operate. In this context it examines whether the ECB is working on a problem solution, and what are the risks posed by Target 2 imbalances for the euro area, as well as whether the euro is volatile and how the Target2 imbalances will be managed if the euro breaks. This research highlights the ambiguity of central bank activities, explains the burdens and risks of Germany as the largest creditor, shows solutions through the communitization or the creation of Target 3 to correct past mistakes and to prevent a further and more severe global crisis. Attention is drawn to the fact that Italy could put the Eurozone in a critical situation by introducing mini-BOTs (small government bonds; "titoli di Stato di piccolo taglio") as the second currency. Furthermore, it is pointed out that the ECB has adjusted its price stability objectives to raise inflation expectations in the Eurozone, which is unlikely to satisfy Target 2 demanding countries.
\end{abstract}

Keywords

Target2, public sector purchase program, Eurozone crisis

JEL Classification

E42, E58, F45

\section{INTRODUCTION}

For more than a decade, various continental economic crises have emerged, which, when aggregated, have led to the worst global economic crisis since 1930 (Kotz, 2009; Stockhammer, 2015). There is consensus that this crisis was caused by the collapse of the US mortgage market, in particular subprime mortgage finance combined with credit derivatives, followed by the collapse of Lehman Brothers investment bank (Golub, Kaya, \& Reay, 2015; Lane, 2012; Sinn, 2018). Numerous financial market players and countries are still struggling with the consequences of the global crisis (Bell \& Hindmoor, 2017). The subject of this paper is the European Union and, more precisely, the Eurozone. It is recognized that two economic areas within the Eurozone have emerged with different dynamics: first, the coordinated market economies, which include Germany, the Netherlands, Belgium, Austria and Finland and form the core of the Eurozone, and second, the mixed market economies, which include Greece, Italy, Spain, Portugal and Cyprus (Dimitriou \& Metaxas, 2018). Both areas were equally affected by the first shock wave in asset-backed securities in 2008, first on the banking market and followed by the sovereign debt crisis (Lane, 2012). The primary financial crisis spread to European countries in 2008 as cross-border financial flows dried up (Milesi-Ferretti \& Tille, 2011). Initially, countries that refinanced themselves on short-term debt markets were affected, followed by further crisis deterioration due to 
a deficit/GDP perspective that has increased significantly in some countries (Mody \& Sandri, 2012). As a result, credit spreads and yield spreads on sovereign bonds between coordinated market economies and mixed market economies, which tended to be zero in the pre-crisis period, expanded considerably over all maturities and fluctuated significantly (Lane, 2012). Italy and Spain were particularly affected in 2011 and 2012, as these countries underwent capital changes due to local crises (Cecchetti, McCauley, \& McGuire, 2012; Febrero, Uxó, \& Álvarez, 2019; Merler \& Pisani-Ferry, 2012). While Spain suffered a real estate bubble with substantial credit financing (leading to market distortions and capital flight), problems in Italy were linked to high public debt and low economic growth, which remain unchanged today (Febrero, Uxó, \& Álvarez, 2019; Quaglia \& Royo, 2014). Risks of sovereign default and high investments in Italy and Spain have led to a significant expansion of yield spreads among sovereign bonds in the Eurozone (Febrero, Uxó, \& Álvarez, 2019). According to Dimitriou and Metaxas (2018), some countries have achieved a better way out of the crisis, while other countries are still facing significant difficulties. Various European policy initiatives have differently influenced market assessments of sovereign default risks and the fragility of the banking sector during the sovereign debt crisis. In particular, mention should be made of the European Central Bank (ECB) policy actions on monetary and financial support, as well as EU and domestic austerity programs (Bergman, Hutchison, \& Hougaard, 2019).

To limit various problems, central banks have massively eased monetary policy and implemented new unconventional measures to stabilize the European situation (Afonso \& Jalles, 2019). However, the results of operations have had an impact on the balance sheets of respective national central banks (NCBs), as will be discussed below. Regarding these balance sheets, significant structural changes have occurred due to TARGET2 (T2) clearing activities (Sinn \& Wollmershäuser, 2012). The Trans-European Automated Realtime Gross Settlement Express Transfer System (TARGET) has the task of processing payments within the European Monetary Union. Cash flows are aggregated and netted in the settlement of cross-border payments. The result is an NCB's claim like the Bundesbank's (Deutsche Bundesbank, 2017, 2018) one against, or on the opposite side, a liability to another central bank in the Eurozone with the central counterpart, ECB. Balance sheet items are not be settled (other assets and other liabilities remain) and may pose a serious problem for some euro members in the future unless they are not completely cleared.

This article discusses different perspectives on $\mathrm{T} 2$ balances in a literature review. It also examines the role of the ECB in crisis management and the risks of T2 imbalances for the Eurozone. It analyzes what will happen to T2 balances if the euro breaks, and discusses the measures recently launched by the ECB. Finally, the paper provides proposals to restrain risks in the Eurozone.

\section{LITERATURE REVIEW}

The first publications on T2 have already appeared from Garber (1998) and Whittaker (2011), although the publications of Sinn (Sinn, 2011a; Sinn \& Wollmershäuser, 2011) have significantly increased the importance of the problem in the area. Since then, T2 imbalances have been discussed controversially and from different perspectives in the scientific literature. Some authors have primarily examined the origin and technique of the balances and concentrated on the beginning of the 2008 financial crisis (Auer, 2013; Mayer, Möbert, \& Weistroffer, 2012; Sinn, 2011a, 2012b). Sinn (2011a) described T2 borrowing as a serious mistake in the euro system, which became obvious and well-known about the debt crisis. According to Sinn, T2 favors credit-weak members of the euro alliance at the expense of stronger Eurozone countries, which ultimately leads to the effect that balances bias the countries' capital allocation and external debt. As a result, the ECB's ability to intervene and control the situation is severely hampered. Sinn (2011a) also compares the Eurozone system with the system in the USA, where this form of credit has to be backed each year by gold-collateralized securities or other marketable, normal-rate securities using the Inter-district Settlement Account. Thus, money production in the USA will only be possible in the long term if real and marketable assets are transferred and balance sheets are settled. 
Other authors take a different perspective and focus on economic aspects rather than explaining T2 (Bindseil \& König, 2012; Mody \& Bornhorst, 2012). Such authors focus on capital flows within the Eurozone and explain strong capital flows to the Federal Republic of Germany, originating from the Southern European economies. They point out that struggling and distressed countries are experiencing difficulties in capital financing, leading to high volatility in credit spreads. In contrast, Gros (2017) points towards short-term discrepancies rather than countries' permanent credit spread expansion.

Cour-Thimann (2013), Széceényi (2015) and Febrero, Uxó, and Álvarez (2019) have provided an overview and explanation of the accounting technique for cross-border payments and bank funding, as well as the risks of T2 balances and evaluation by comparison with the USA. Fahrholz and Freytag (2012) and Sinn (2012a) have discussed solutions and evaluated the ECB's activities from a long-term perspective. According to Széceényi (2015), opinions in the literature on the origin of imbalances, the content of assets and T2 liabilities and reasons for the structure of the balances are very different. Febrero, Uxó, and Álvarez (2019) cannot support the official statement of the ECB (European Central Bank, 2017a) on the increase in T2 imbalances, as they argued that the empirical evidence available for Italy and Spain contradicts the ECB's explanation.

\section{METHOD}

Using a quantitative time series analysis, the paper examines whether the ECB is part of the problem or does it help to solve the problem?

T2 imbalances in the Eurozone have led to a significant balance variance. Although claims by countries after 2012, the previous peak so far, have almost halved by mid-2014, the gap between Germany, Luxembourg, Finland and the Netherlands vis-à-vis the other Eurozone countries has widened significantly and reached a new record level. In particular, mixed market economies have created significant unsecured liabilities to the ECB/coordinated market econ- omies. Between mid-2011 and late 2012, there was a similar development as in mid-2014, but the reasons for the imbalance are different because they are more extensive. Although for economic reasons the development of the T2 balance probably evolved by 2012 , another aspect has been important since mid-2014. The ECB has launched the Quantitative Easing (QE) Programme in several steps. First, corporate bonds, covered bonds and government securities were bought by the ECB, followed by other measures primarily aimed at exerting an upward pressure on inflation to reach a $2 \%$ level and to increase lending within the Eurozone (Széceényi, 2015). The ECB's purchase program was conducted through various individual programs (not fully shown here) under the auspices of the ECB. For this paper, the essential programs to consider were:

March 2015: The ECB launched the Public Purchase Programme (PSPP). Compared to previous programs, the PSPP allowed NCBs to purchase only their own government bonds to address concerns about unauthorized monetary financing (European Central Bank, 2017b).

June 2016: Central banks were allowed to acquire corporate bonds through the Corporate Sector Purchase Programme (CSPP) issued by Eurozone issuers. CSPP purchases are carried out by six NCBs acting on behalf of the ECB. Unlike government bond purchases, central banks were able to subscribe to or buy corporate bonds directly from issuers (European Central Bank, 2018a).

It should be noted in this context that in the middle of 2012, ECB chief Draghi's speech 'Whatever it takes' again reduced $\mathrm{T} 2$ balances and made the discussed collapse of the Eurozone less relevant. Both trust and investments were available for almost three years according to ECB T2 balances. Since 2015, with the start of the QE, T2 balances have again changed a lot. Opinions about debt levels, consequences and possible financial implications for each country diverge and are described below in this paper.

With the PSPP implementation, the Bundesbank's T2 accounts receivable increased by around EUR 400 billion to EUR 910 billion. The T2 accounts 
Table 1. T2 balances in million EUR between March 2015 and May 2019

Source: ECB's Statistical Data Warehouse (monthly averages of daily data).

\begin{tabular}{|c|c|c|c|}
\hline Country & March-15 & May-19 & Delta \\
\hline Germany & 520,634 & 910,683 & 390,049 \\
\hline Luxembourg & 105,311 & 225,199 & 119,889 \\
\hline Netherlands & 13,980 & 91,520 & 77,540 \\
\hline Greece & $-93,283$ & $-23,203$ & 70,079 \\
\hline France & $-69,916$ & $-14,093$ & 55,823 \\
\hline Ireland & $-16,043$ & 19,966 & 36,009 \\
\hline Finland & 16,585 & 49,040 & 32,455 \\
\hline Cyprus & $-1,657$ & 8,689 & 10,346 \\
\hline Slovakia & 595 & 9,771 & 9,176 \\
\hline Malta & $-1,308$ & 4,522 & 5,830 \\
\hline Austria & $-38,437$ & $-38,570$ & -132 \\
\hline Estonia & 704 & 227 & -478 \\
\hline Slovenia & 2,553 & 600 & $-1,953$ \\
\hline Latvia & $-2,514$ & $-5,363$ & $-2,849$ \\
\hline Lithuania & -609 & $-3,459$ & $-2,851$ \\
\hline Belgium & $-9,476$ & $-15,812$ & $-6,336$ \\
\hline Portugal & $-48,524$ & $-78,894$ & $-30,371$ \\
\hline $\mathrm{ECB}$ & $-29,490$ & $-251,678$ & $-222,188$ \\
\hline Spain & $-187,900$ & $-410,095$ & $-222,195$ \\
\hline Italy & $-162,303$ & $-482,646$ & $-320,344$ \\
\hline
\end{tabular}

Table 2. T2 balances in million EUR between December 2018 and May 2019

Source: ECB's Statistical Data Warehouse (monthly averages of daily data).

\begin{tabular}{|c|c|c|c|c|c|}
\hline Country & December-18 & April-19 & $\begin{array}{c}\text { Delta } \\
\text { December-18 to April-19 }\end{array}$ & May-19 & $\begin{array}{c}\text { Delta } \\
\text { April-19 to May-19 }\end{array}$ \\
\hline Austria & $-40,328$ & $-41,707$ & $-1,379$ & $-38,570$ & 3,137 \\
\hline Belgium & $-14,869$ & $-11,916$ & 2,953 & $-15,812$ & $-3,896$ \\
\hline Cyprus & 7,896 & 7,370 & -526 & 8,689 & 1,319 \\
\hline Germany & 932,203 & 899,867 & $-32,336$ & 910,683 & 10,816 \\
\hline Luxembourg & 213,504 & 219,255 & 5,750 & 225,199 & 5,944 \\
\hline Netherlands & 112,653 & 88,052 & $-24,602$ & 91,520 & 3,469 \\
\hline Finland & 47,200 & 58,559 & 11,359 & 49,040 & $-9,519$ \\
\hline Estonia & -206 & -41 & 165 & 227 & 268 \\
\hline France & $-33,270$ & $-6,431$ & 26,839 & $-14,093$ & $-7,661$ \\
\hline Greece & $-28,766$ & $-24,159$ & 4,608 & $-23,203$ & 956 \\
\hline Portugal & $-82,185$ & $-79,814$ & 2,372 & $-78,894$ & 919 \\
\hline ECB & $-249,301$ & $-252,037$ & $-2,736$ & $-251,678$ & 359 \\
\hline Spain & $-403,194$ & $-398,277$ & 4,917 & $-410,095$ & $-11,817$ \\
\hline Italy & $-481,590$ & $-487,379$ & $-5,789$ & $-482,646$ & 4,733 \\
\hline Ireland & 14,507 & 20,446 & 5,940 & 19,966 & -481 \\
\hline Lithuania & $-5,136$ & $-4,002$ & 1,134 & $-3,459$ & 543 \\
\hline Latvia & $-6,851$ & $-5,635$ & 1,216 & $-5,363$ & 272 \\
\hline Malta & 3,550 & 4,334 & 785 & 4,522 & 188 \\
\hline Slovenia & 1,167 & 250 & -917 & 600 & 350 \\
\hline Slovakia & 9,582 & 9,539 & -43 & 9,771 & 232 \\
\hline
\end{tabular}

receivable of the Banque Centrale du Luxembourg doubled in the same period from EUR 105 billion to EUR 225 billion. At the same time, QE led to a combined increase in the T2 liabilities of the central banks of Italy and Spain of around EUR 550 billion.
The T2 balances of the Bundesbank have temporarily recovered when the ECB's QE program expired in December 2018 and fell by EUR 32 billion within four months. Similar development has taken place in the Netherlands. While Spain reduced its obligation, Italy continued expanding its pay- 


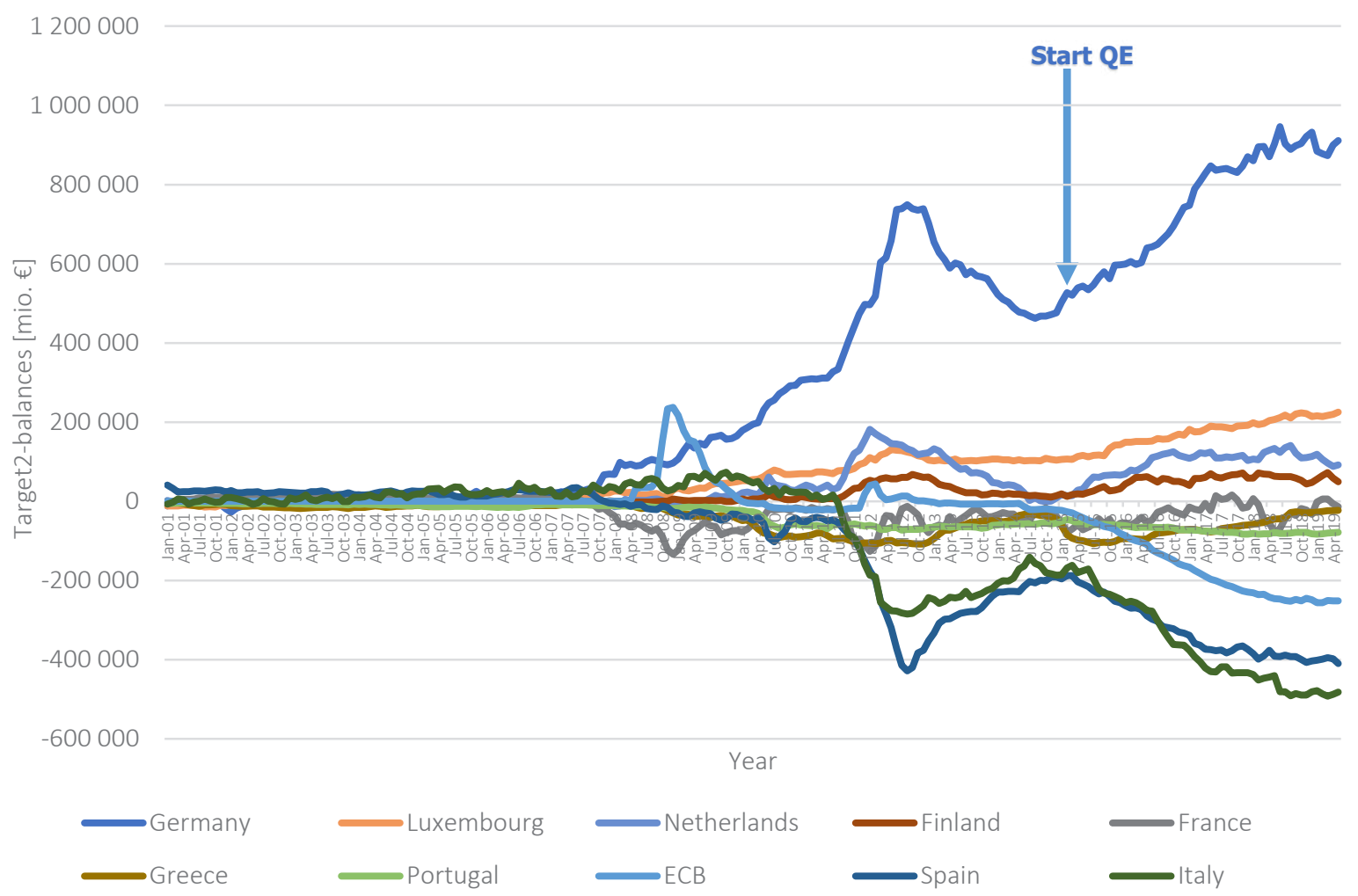

Figure 1. T2 balances in million EUR for selected countries: long-term and by country

ment obligation due to ongoing political tension. Movements in Finland, Luxembourg and France are surprising. While France has reduced its T2 payment obligation, Finland and Luxembourg have built up further receivables. The ECB's announcement of the resumption of QE programs in May 2019 promptly initiated a further balance move. Nevertheless, the development is again very different. While the demands of Germany, the Netherlands and Luxembourg immediately rose again, Finland and France immediately changed. Spain and Italy also went differently. However, in general, the trend remained intact, and the demands of a coordinated market economy are expected to continue to increase once the ECB resumes the programs. In particular, Germany is expected to generate an even higher receivable portfolio, which will reach a significant, difficult-to-control level (see Figure 1).

In addition to macroeconomic shifts since 2015, the ECB has purchased around EUR 233.9 billion in bonds via banks (European Central Bank, 2018a). At the same time, the ECB's negative T2 balance was build up to the same level (Figure 1; ECB level). Funds received by those who have sold the bonds cannot be deposited with the ECB. Consequently, asset purchases by the ECB will inevitably result in a negative T2 balance for the ECB. An adjustment item is then an accumulation of surplus reserves somewhere in the Eurozone, with some of the NCBs having a positive (or less negative) balance as a result of the ECB's purchases (Gros, 2017).

The ECB began acquiring securities in the fourth quarter of 2014 as part of the third Covered Bond Purchase Programme (CBPP3) and AssetBacked Securities Purchase Programme (ABSPP; European Central Bank, 2018). These activities were continued in the following years. In 2018, total ECB assets increased by EUR 32.9 billion to EUR 447.1 billion, mainly as a result of the ECB's Asset Purchase Programme (APP). In 2018, growth slowed due to the decline in APP monthly purchases. As a result of purchases, the balance sheet item 'Securities held for monetary policy purposes' continued to grow. At the same 
Table 3. ECB balance sheets total and securities held for monetary policy purposes (2014-2018)

Source: ECB extended financial statements (European Central Bank, 2018a,b) and author's development.

\begin{tabular}{|c|c|c|c|c|c|}
\hline Assets in billions of Euros & 2014 & 2015 & 2016 & 2017 & 2018 \\
\hline Foreign reserve & 62.2 & 67.4 & 71.4 & 65.7 & 69.6 \\
\hline Securities held for monetary policy purposes & 17.8 & 77.8 & 160.8 & 228.4 & 251.7 \\
\hline Intra-Eurosystem receivables & 81.3 & 86.7 & 90.1 & 93.7 & 98.5 \\
\hline Other assets & 24 & 24.8 & 26.6 & 26.4 & 27.3 \\
\hline Balance sheet total & 185.3 & 256.7 & 348.9 & 414.2 & 447.1 \\
\hline Liabilities in billions of Euros & 2014 & 2015 & 2016 & 2017 & 2018 \\
\hline Banknotes in circulation & 81.3 & 86.7 & 90.1 & 93.7 & 98.5 \\
\hline Intra-Eurosystem liabilities & 64.1 & 123.9 & 192 & 258.5 & 283.9 \\
\hline Other liabilities & 3.7 & 4.7 & 21.7 & 23.4 & 22.8 \\
\hline General risk provision, revaluation account, capital, reserves and net income & 36.2 & 41.3 & 45.2 & 38.6 & 41.9 \\
\hline
\end{tabular}

time, cash settlements of these purchases via T2 accounts led to a corresponding increase in intra-Eurozone liabilities (European Central Bank, 2018a). If in 2014, the portfolio of securities held for monetary policy purposes was around $10 \%$ of the total balance sheet (Table 3), in 2018 the proportion increased to over $55 \%$. The majority of securities (78\%) originate from the PSPP (European Central Bank, 2018).

\section{RESULTS}

\subsection{Key risks from $T 2$ imbalances}

The high indebtedness of mixed market economies due to the large current account deficits could no longer be refinanced in the capital market from 2008 onwards during the financial crisis. The ECB provided cash in the form of refinancing loans, which were made available, inter alia, by the Bundesbank through reserves (Febrero, Uxó, \& Álvarez, 2019). Germany was forced to export money over the Bundesbank, as the existing system does not provide for a compensation mechanism or limits (Sinn, 2011b). Because the amounts are infinite, there are considerable default risks for lenders in the amount of the imbalance. However, cross-border debt cannot be reduced without a substantial foreign trade surplus of T2 debtor countries and may lead to a dissolution of the euro in future (Sinn, 2011c). Febrero, Uxó, and Álvarez (2019) disagree with Sinn (2011b, 2011c) and provide three arguments:

- T2 imbalance risks are refinancing loans granted by NCBs to banks in their respective countries. The risk of being inactive and not supporting solvent but illiquid banks, even against collateral and a high Return on Risk Adjusted Capital (RORAC), is much higher for the economic system, including the central bank, than for the central bank as a lender of last resort.

- The ECB reversed the events following the Greek crisis in early 2011, the subsequent relocation of investments to Germany (the 'supposedly safe haven') and the lack of investment in Italy and Spain, among others, in mid-2012 through Outright Monetary Transactions (OMT).

- Provision of reserves for debtor economies enables creditors (and, indirectly, banks) to redeem their risky investments in mixed market economies, while stocks of non-performing loans must be refinanced by countries in mixed market economies on international markets and thus remain in the balance sheets (of the banks). Thus, creditor countries (resident banks) significantly reduce their default risk.

\subsection{Is the Eurozone unstable and do euro area countries face increasing threats?}

There are different opinions, and there is no consensus in the literature as to whether the Eurozone is unstable and whether euro area countries face increased financial threats. According to Gros (2017), the Eurozone is not unstable for the following reasons:

- Risk premiums usually do not increase. Banks in countries where the target balances have turned negative face no serious problems 
in accessing interbank and capital markets. Countries (except, temporarily, Greece), have had uninterrupted access to the markets. Meanwhile, Greece has successfully returned to capital markets as an issuer.

- T2 balances reflect geographical differences in the distribution of central bank deposits compared to purchases of securities by NCBs and ECB. As a result, deposits reach those countries where banks generate the most cash surplus. The largest cash surpluses have flowed into the countries with the highest current account surpluses.

- Developments in Greece are remarkable, as the NCB did not participate in PSPP purchases of securities. If the euro system was significantly unstable and there was a flight of capital, the T2 balance of Greece could be expected to deteriorate, but that did not happen. T2 balances have improved sharply since the strong surge due to political tensions in early 2015.

Euro area Financial markets Data are not fully integrated and homogenized, which is primarily a problem for high T2 balances according to Gros (2017), who discerns no loss of trust and confi- dence. These accounting records ultimately reflect the functioning of the monetary union. T2 balances are a consequence of the decentralized implementation of the common monetary policy. According to Gros (2017), if all bond purchases were made by the ECB (rather than NCBs), most countries would have to report positive balances.

Other authors find T2 balances much more complex and critical. Blake (2018) noted that this deficit can never be eliminated and, therefore, the euro can only survive if Germany, in particular, agrees that the Eurozone's debts will be communitarized, transforming the Eurozone into a transfer union. Sinn and Wollmershäuser (2011) have argued that countries with positive T2 balances, like Finland, the Netherlands, Luxembourg and Germany, face the risk of losing the claims of their NCBs in case of a euro breakup.

\section{DISCUSSION}

\subsection{What would happen to $T_{2}$ if the euro broke?}

According to Sinn (2012b), if the euro breaks, T2 claims will lose their legal base, because they are

Source: ECB's Statistical Data Warehouse (monthly averages of daily data).

T2 balance -Greece 2001 -2019

20000

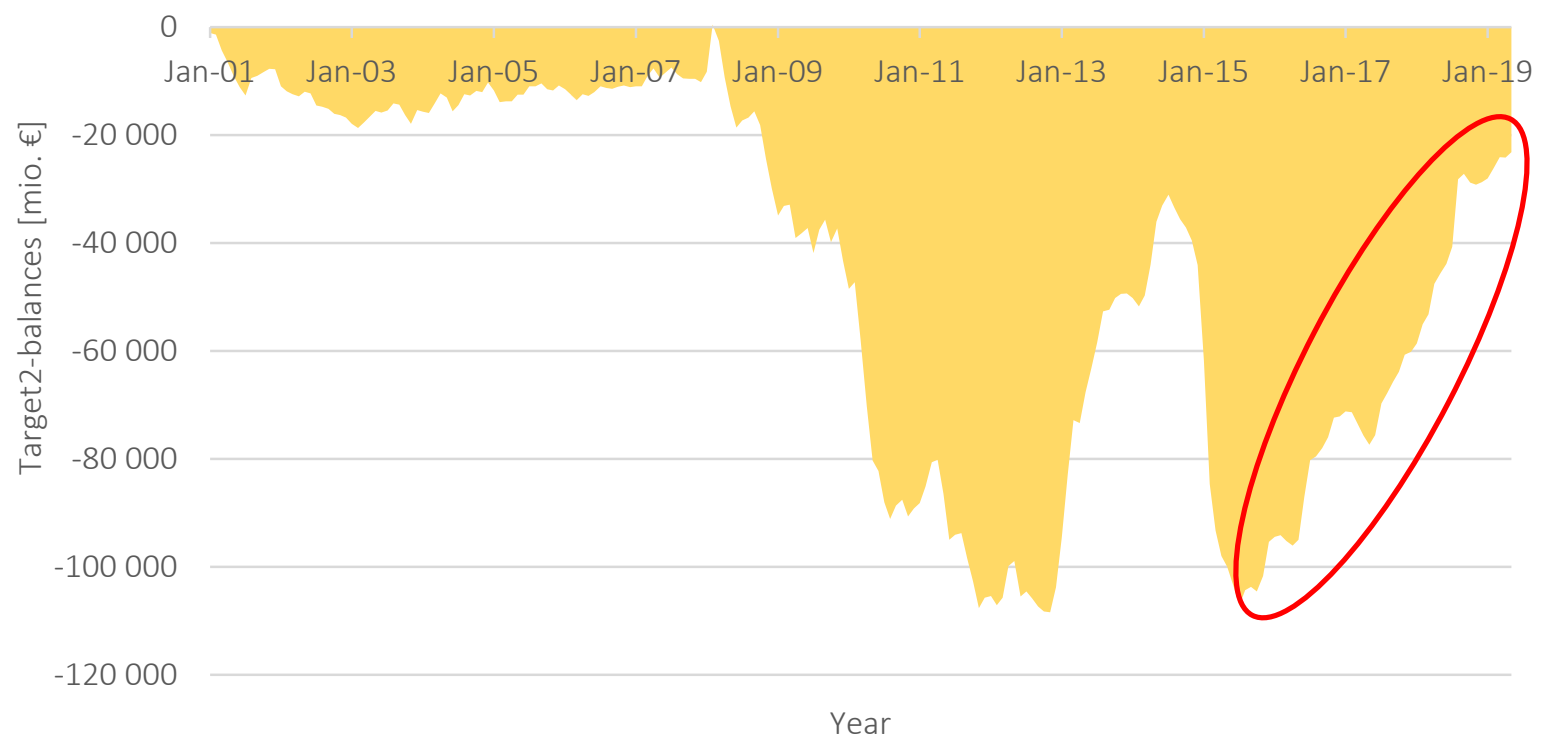

Figure 2. T2 balances of Greece in billion EUR 
claims against a system that would no longer exist and because there are no legal rules and specifications in the ECB system to deal with such a case. The ECB's equity capital cannot cover current T2 liabilities (European Central Bank, 2018b). This will mean real capital losses for taxpayers and/or savers in a surplus country whose present value corresponds to T2 balances. In this regard, Helmut Schlesinger, former President of the Bundesbank, requires a higher penalty interest for T2 liabilities to be paid to creditor countries by debtor countries (Sinn, 2012a). The Eurozone needs a regulating and dampening buffer to mitigate and prevent T2 extremes (Sinn, 2012a). If the euro is dissolved or a withdrawal occurs, the ECB believes that liabilities must be settled. The ECB refers to the TARGET guidelines for 2012 (ECB, 2013). However, the legal opinion on this issue is not clear, since there is no legally binding text or law, according to Häring (2018).

Financial risk, such as the Bundesbank's risk (and thus Germany's), is indirect (Braunberger, 2018). The ECB withhold bonds from the purchase programs and it owns T2 claims against the NCBs. Even when the country leaves the euro, the ECB will not need to adjust the value of its claims, since its $\mathrm{T} 2$ requirements are indefinite and no obligation to repay exists. In addition, the claims are interest-free. Probably, after a severe depreciation of an exit country, countries may be so attractive that capital flows into countries. This effect will help to reduce the accumulated T2 balances against the ECB. However, the ECB still has bonds that need to be written down. Depreciation will probably cause a lot of damage, but it will be much less than the current balance of the T2 program (Braunberger, 2018).

\subsection{Changes to the ECB strategy in 2019}

The ECB's previous inflation target of just below $2 \%$ in the Eurozone was still considered desirable (European Central Bank, 2019a). Unlike the earlier asymmetric inflation target of less than $2 \%$, the ECB emphasizes a symmetric ECB inflation target and has recently announced that a higher inflation rate of 2\% will also be accepted (European Central Bank, 2019b). Monetary policy activities are, therefore, not to be expected in the event of increasing inflation. The ECB has prepared market participants for further expansionary monetary policy, thereby abandoning the previous central inflation target. In conclusion, the ECB's effort to steer inflation levels upward by its previous activities have not yet been successful.

The ECB's activities confirm creditor countries' fears of T2 balances. Since some debtor countries, including Italy, have not solved their structural budget problems and $\mathrm{T} 2$ balances are de facto without an upper limit, creditor countries see the moral hazard problem for debtor countries. Creditor countries prefer that debtor countries take deflationary measures to convert their foreign trade into a surplus and thus reduce their debt (Febrero, Uxó, \& Álvarez, 2019). Italy's uncertain and unstable orientation is leading to a completely different approach. At the moment, Calming is only a temporary and volatile political situation in Italy. The possible design of Mini-bills of treasury (BOTs) inevitably leads to the question of whether these promissory notes also have essential characteristics of money as a means of exchange and payment. Neither the fixed term nor an interest rate or a guarantee are considered. Design as a paper certificate also leads to this consideration. Italy's financial stability is inevitably linked to increased risks, and Italy's exit from the Eurozone is expected to happen if this scenario holds.

The reason for changes to the ECB's strategy is probably in an expectation that inflation rates above $2 \%$ will be tolerated in the medium term. Despite the announcement of renewed monetary policy measures and a reduction in deposit rates - as well as the resumption of the bond purchase program - inflation has recently fallen again. The ECB's announcement of a new inflation target fuels fears that an expansive monetary policy is likely to continue, even if economic activity improves and inflation rates increase in the future. However, a revised strategic approach to inflation expectations and inflation target may also entail risks that the ECB may not succeed with planned measures, thereby casting doubt on the ECB's ability to effectively control inflation. In addition, it is questionable whether the ECB, with its focus on price stability measured by annual inflation, is generally property targeted. Globalization, technological advances and demography have considerably changed the previous focus on the price-level stability. The ECB may experience a controlling illusion that could prove fatal for the Eurozone in the future. 


\section{Inflation rates for the Euro area (1997-2019), annualized}

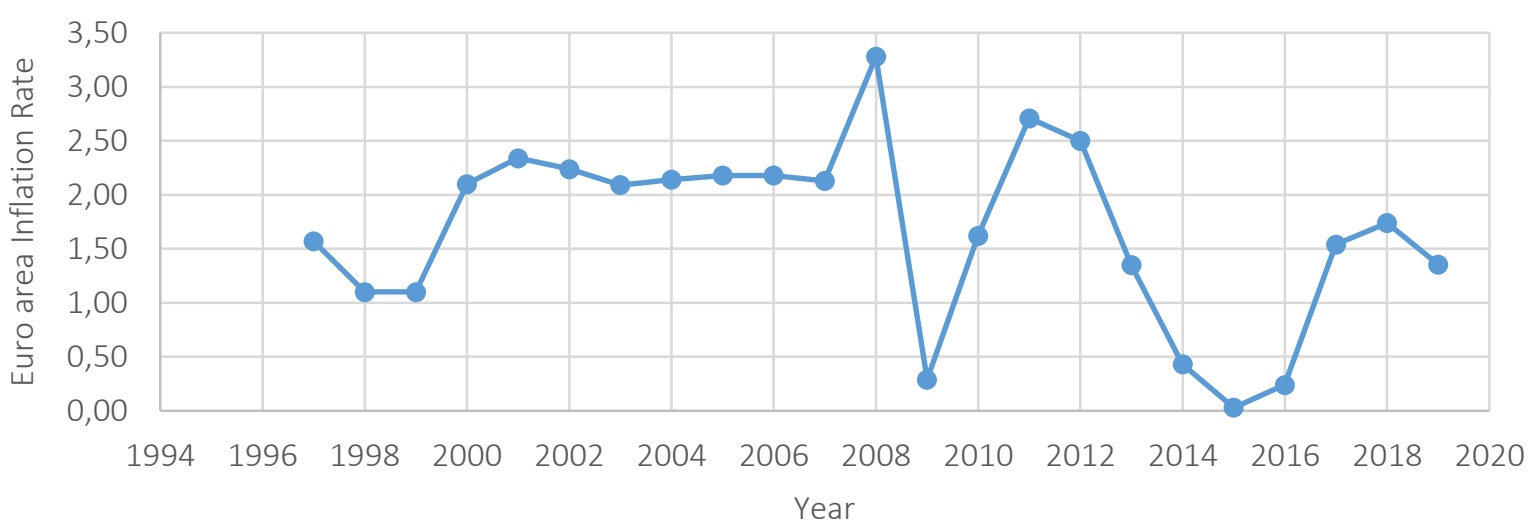

Figure 3. Inflation rates for the Euro area (1997-2019), annualized data

\section{CONCLUSION}

The activities of the ECB and NCBs had a significant impact on the renewed expansion of T2 balances. Balances primarily have a long-term effect; short-term changes lead to distortions of previous long-term trends. Whether the amount of balances is a problem for the ECB, the NCBs and, therefore, for the countries that have claims to the ECB, is a controversy discussed in the existing literature. Although one faction sees no permanent problem, as the risk premium of debtor countries has not increased and T2 is dismissed as a temporary geographical problem due to the lack of integration and homogenization of the financial markets, other factions see a serious problem due to the level of Germany's claims, which can only be solved by debt communitization. However, such an implementation should not be expected.

The two economic areas within the Eurozone are still widely separated, but the structural problems of the mixed market economies have not been addressed, the economy in the Eurozone is not improving and the ECB's instruments are becoming increasingly ineffective, aggravated also by the effect of the reverse interest rate (Brunnermeier \& Koby, 2016). As a result, Germany, as a previous driving force in the Eurozone, is increasingly weakened, with the ECB trying to gain time through inflation, although the ensuing crisis, which will certainly follow, will cause severe volatility in the mixed market economies. However, the ECB is steadfast in its actions, and the creeping process of T2 balances is unbroken, formulated with the help of the ECB's Forward Guidance.

ECB's activities to stabilize the Eurozone and its QE program are very controversial in politics and science. Unfortunately, the size of NCBs' claims is not a small matter. Therefore, the NCB of countries with ECB requirements must insist on clarifying the current unclear legal situation. The political situation in the Eurozone is now under intense debate. Eurozone sovereign bond credit spreads are still highly volatile and consistent with market spreads and risks. In any case, a solution to the T2 balance problem should be sought to avoid unnecessary uncertainty and speculation with sovereign spreads. If there is no consensus on T2 balances in the Eurozone, there is a strong need to establish a new TARGET3 program. Presumably, only the Bundesbank could enforce this because of its claim position against the ECB. If the Bundesbank is no longer prepared to accept T2 offsetting without collateral, it must enforce necessary pressure to launch TARGET3. In addition, the Bundesbank and the ECB must insist on their position on future balance offsetting in the event of a member's exit or the ECB insolvency. In any case, the legal situation in the Eurozone must be clarified immediately to avoid (further) instability. 
Despite different views on the risks of T2 balances in the euro area, the fact remains that, due to the lack of a supra-national fiscal authority, the euro area has significant instabilities and is, therefore, more vulnerable to crises (Barba \& Vivi, 2013; Febrero, Uxó, \& Álvarez, 2019). The political instability in Italy is very risky for the Eurozone. If Italy introduces a second currency with mini-BOTs (Meyer, 2020), this could lead to the exclusion of Italy from the euro, as the euro will weaken considerably and Italy will slide into the next financial crisis. The exclusion of Italy with the relevant T2 demands from the ECB and the legally ambiguous situation can lead to considerable uncertainty in the Eurozone.

\section{REFERENCES}

1. Afonso, A., \& Jalles, J. (2019). Quantitative easing and sovereign yield spreads: Euro-Area time-varying evidence. Journal of International Financial Markets, Institutions and Money, 58(C), 208-224. https:// doi.org/10.1016/j.intfin.2018.10.003

2. Auer, R. (2013). What Drives Target2 Balances? Evidence from a Panel Analysis (CESifo Working Paper No. 4216). Retrieved from https://papers. ssrn.com/sol3/papers.cfm?abstract_ $\mathrm{id}=2258414$

3. Barba, A., \& De Vivo, G. (2013). Flawed currency areas and viable currency areas: external imbalances and public finance in the time of the euro. Contributions to Political Economy, 32(1), 73-96. https://doi. org/10.1093/cpe/bzt003

4. Bell, S., \& Hindmoor, A. (2017). Are the major global banks now safer? Structural continuities and change in banking and finance since the 2008 crisis. Review of International Political Economy, 25(1), 1-27. https://doi.org/10.1080/09692290.2 017.1414070

5. Bergman, M. U., Hutchison, M. M., \& Hougaard, J. S. E. (2019). European policy and markets: Did policy initiatives stem the sovereign debt crisis in the Euro Area? European Journal of Political Economy, 57(C), 3-21. https://doi.org/10.1016/j.ejpoleco.2018.06.003

6. Bindseil, U., \& König, P. J. (2012). TARGET2 and the European Sovereign Debt Crisis. Kredit und Kapital, 45(2), 135-174. https://doi. org/10.3790/kuk.45.2.135

7. Blake, D. (2018). Target2: The silent bailout system that keeps the Euro afloat (Working Paper) London: City, University of London. Retrieved from https://openaccess.city.
ac.uk/id/eprint/19674/1/Target\%20

2\%20vla.pdf

8. Braunberger, G. (2018, July 3). Das Anleihekaufprogramm der EZB treibt den Target-2-Saldo (Blog). Frankfurter Allgemeine. Retrieved from http://blogs.faz.net/fazit/2018/07/03/das-anleihekaufprogramm-der-ezb-treibt-den-target2-saldo-10130/

9. Brunnermeier, M., \& Koby, Y. (2016). The "Reversal Interest Rate": An Effective Lower Bound on Monetary Policy. Princeton University. Retrieved from https://scholar. princeton.edu/sites/default/files/ markus/files/17e_reversalrate.pdf

10. Cecchetti, S. G., McCauley, R. N., \& McGuire, P. M. (2012). Interpreting TARGET2 balances (BIS Working Papers No. 393). Monetary and Economic Department. Bank for International Settlements. Retrieved from https://www.bis.org/publ/ work393.pdf

11. Cour-Thimann, P. (2013). Target Balances and the Crisis in the Euro Area. CESifo Forum, 14(Special Issue), 5-50. Retrieved from https:// www.sfm.econ.uni-muenchen.de/ lehre/monetary-policy/literatur/ forum-sonderheft-apr-2013.pdf

12. Deutsche Bundesbank. (2017). Annual Report 2017. Retrieved from https://www.db.com/ir/en/download/DB_Annual_Report_2017.pdf

13. Deutsche Bundesbank. (2018). An nual Report 2018. Retrieved from https://www.db.com/ir/en/download/Deutsche_Bank_Annual_Report_2018.pdf

14. Dimitriou, G., \& Metaxas, T. (2018). Mapping economic crisis in South Europe: Greece, Portugal and Cyprus (MPRA Paper). Retrieved from https://mpra.ub.uni-muenchen. de/87373/

15. European Central Bank (ECB). (2013). Guideline (ECB/2012/27) on a Trans-European Automated Real-time Gross settlement Express Transfer system (TARGET2) (Non-legislative acts). Official Journal of the European Union, L30, 1-93. Retrieved from https:// www.ecb.europa.eu/ecb/legal/pdf/ 1_03020130130en00010093.pdf

16. European Central Bank (ECB). (2017a). Implementation aspects of the public sector purchase programme (PSPP). Retrieved from https://www.ecb.europa.eu/mopo/ implement/omt/html/pspp.en.html (Last update: 2020, January 22).

17. European Central Bank (ECB). (2017b). The ECB's asset purchase programme and TARGET balances: monetary policy implementation and beyond. ECB Economic Bulletin, 3, 21-26. Retrieved from https:// www.ecb.europa.eu/pub/pdf/other/ ebbox201703_01.en.pdf

18. European Central Bank (ECB). (2018a). Corporate sector purchase programme (CSPP) - Questions \& Answers. Retrieved from https:// www.ecb.europa.eu/mopo/implement/omt/html/cspp-qa.en.html (updated on 6/29/2018).

19. European Central Bank (ECB). (2018b). Erweiterter Jahresabschluss. Retrieved from https://www.ecb. europa.eu/pub/pdf/annrep/ecb. annualaccounts2018 cd3eabaa40. de.pdf

20. European Central Bank (ECB). (2019a). Definition of price stability. Quantitative definition. Retrieved from https://www.ecb.europa.eu/ mopo/strategy/pricestab/html/index.en.html 
21. European Central Bank (ECB). (2019b). Twenty Years of the ECB's monetary policy (Speech by Mario Draghi, President of the ECB). ECB Forum on Central Banking, Sintra. Retrieved from https://www.ecb.europa.eu/press/key/date/2019/html/ ecb.sp190618 ec4cd2443b.en.html

22. European Central Bank (ECB). (n.d.). Asset purchase programmes. Expanded asset purchase programme. Retrieved from https://www.ecb. europa.eu/mopo/implement/omt/ $\mathrm{html} /$ index.en.html

23. Fahrholz, C., \& Freytag, A. (2012). Will Target2-Balances be Reduced again after an End of the Crisis (Global Financial Markets Working Papers No. 30). Friedrich-SchillerUniversity Jena. Retrieved from https://econpapers.repec.org/paper/ hljhljwrp/30-2012.htm

24. Febrero, E., Uxó, J., \& Álvarez, I. (2019). Target 2 Imbalances and the ECB's Asset Purchase Programme. An alternative account. Panoeconomicus, 1-21. https://doi org/10.2298/PAN180627008F

25. Garber, P. M. (1998). Notes on the role of target in a Stage III crisis (NBER Working Paper No. 6619). Cambridge: Natioal Bureau of Economic Research. Retrieved from https://www.nber.org/papers/w6619

26. Golub, S. S., Kaya, A., \& Reay, M. (2015). What Were They Thinking? The Federal Reserve In The RunUp To The 2008 Financial Crisis. Review of International Political Economy, 22(4), 657-692. https://doi. org/10.1080/09692290.2014.932829

27. Gros, D. (2017). Target imbalances at record levels: Should we worry? (CEPS Policy Insights No. 41). Retrieved from https://www.ceps.eu/ ceps-publications/target-imbalances-record-levels-should-we-worry/

28. Häring, N. (2018, June 7). Warum die Bundesbank ein Billionen-EuroProblem hat. Handelsblatt. Retrieved from https://www.handelsblatt. com/finanzen/geldpolitik/targetforderungen-warum-die-bundesbank-ein-billionen-euro-problemhat/22656786.html

29. Kotz, D. M. (2009). The Financial and Economic Crisis of 2008. A Systemic Crisis of Neoliberal Capitalism. Review of Radical Political Economics, 41(3), 305-317. https:// doi.org/10.1177/0486613409335093
30. Lane, P. R. (2012). The European Sovereign Debt Crisis. Journal of Economic Perspectives, 26(3), 49-68. https://doi.org/10.1257/jep.26.3.49

31. Mayer, T., Möbert, J., \& Weistroffer, C. (2012). Macroeconomic Imbalances in EMU and the Eurosystem. CESifo Forum, 13(Special Issue), 35-42. Retrieved from https://core. ac.uk/download/pdf/6654500.pdf

32. Merler, S., \& Pisani-Ferry, J. (2012). Sudden stops on euro area. Review of Economics and Institutions, 3(3), 1-23. http://dx.doi.org/10.5202/rei. v3i3.97

33. Meyer, D. (2020). Mini-Bots: Ein "Liro" als Parallelwährung für Italien? In Europäische Union und Währungsunion in der Dauerkrise (pp. 439-460). Springer, Wiesbaden. Retrieved from https://www. springerprofessional.de/en/minibots-ein-liro-als-parallelwaehrungfuer-italien/17422540

34. Milesi-Ferretti, G.-M., \& Tille, C. (2011). The great retrenchment: international capital flows during the global financial crisis. Economic Policy, 26(66), 285-342. http://dx.doi. org/10.2139/ssrn.1977374

35. Mody, A., \& Bornhorst, F. (2012). TARGET imbalances: Financing the capital-account reversal in Europe. CEPR Policy Portal. Retrieved from https://voxeu.org/article/target-imbalances-financing-capital-accountreversal-europe

36. Mody, A., \& Sandri, D. (2012). The Eurozone crisis: how banks and sovereigns came to be joined at the hip. Economic Policy, 27(70), 199230. Retrieved from https://papers. ssrn.com/sol3/papers.cfm?abstract_ $\mathrm{id}=2035300$

37. Quaglia, L., \& Royo, S. (2014). Banks and the political economy of the sovereign debt crisis in Italy and Spain. Review of International Political Economy, 22(3), 485-507. http://dx.doi.org/10.1080/09692290. 2013.877059

38. Sinn, H.-W. (2011a). Die europäische Zahlungsbilanzkrise. ifo Schnelldienst, 64(16), 3-8. Retrieved from https://www.ifo.de DocDL/ifosd_2011_16_1.pdf

39. Sinn, H.-W. (2011b). Germany's capital exports under the euro (Columns). VOX, CEPR Policy Portal.
Retrieved from https://voxeu.org/ article/germany-s-capital-exportsunder-euro

40. Sinn, H.-W. (2011c). The ECB's stealth bailout (Columns). VOX, CEPR Policy Portal. Retrieved from https://voxeu.org/article/ecb-sstealth-bailout

41. Sinn, H.-W. (2012a). Fed versus ECB: How TARGET debts can be repaid (Columns). VOX, CEPR Policy Portal. Retrieved from https://voxeu. org/article/fed-versus-ecb-howtarget-debts-can-be-repaid

42. Sinn, H.-W. (2012b). Target Losses in Case of a Euro Breakup. CESifo Forum, 13(4), 51-58. Retrieved from https://www.cesifo.org/DocDL/ forum4-12-speciall.pdf

43. Sinn, H.-W. (2018). The ECB's Fiscal Policy (CESifo Working Paper Series No. 7019). CESifo Group Munich. Retrieved from http://www.hanswernersinn.de/ dcs/2018_TheECBsFiscalPolicy_Cesifo_wp7019.pdf

44. Sinn, H.-W., \& Wollmershäuser, T. (2011). Target Loans, Current Account Balances and Capital Flows: The ECB's Rescue Facility (NBER Working Paper No. 17626). Retrieved from http://www.hanswernersinn.de/dcs/2012_ITAX19_ NBER_wp17626_2011.pdf

45. Sinn, H.-W., \& Wollmershäuser, T. (2012). Target balances and the German financial account in light of the European balance-of-payments crisis (CESifo Working Paper No. 4051). Center for Economic Studies and Ifo Institute (CESifo), Munich. Retrieved from https://www.cesifo. org/DocDL/cesifo1_wp4051.pdf

46. Stockhammer, E. (2015). Rising inequality as a cause of the present crisis. Cambridge Journal of Economics, 39(3), 935-958. http://dx.doi. org/10.1093/cje/bet052

47. Széceényi, P. (2015). Nature of TARGET2 Imbalances. Public Finance Quarterly, 60(3), 342-356. Retrieved from https://ideas.repec.org/a/pfq/ journl/v60y2015i3p342-356.html

48. Whittaker, J. (2011). Intra-eurosystem debts. (MPRA Working Paper No. 38368). Retrieved from http:// mpra.ub.uni-muenchen.de/38368/ 